\title{
Barely Plants Response to Nitrogen and Boron Applications Under Water Culture Technique \\ Rahmou, A. A ${ }^{1}$; A. M. El -baalawy ${ }^{2}$ and M. A. B. El - Sherief $^{1}$ \\ 1. Soil, Water and Environment Research. Institute, Agriculture Research Center, Giza. \\ 2. Soil Science Department, Faculty of Agriculture, Menoufia University.
}

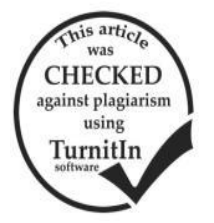

\section{ABSTRACT}

A water culture technique was carried out in Soil Science Department, Faculty of Agriculture, Menoufia university winter season 2015 to study boron and nitrogen requirements and their effect on barely plants grown in a complete nutrient solution containing $\mathrm{N}$ at levels of $0,30,60$ and $90 \mathrm{mg} \mathrm{L}^{-1}$ and $\mathrm{B}$ at levels of $0,2,3,6$ and $9 \mathrm{mg} \mathrm{L}^{-1}$. At 42 days age, plants were harvested, divided into roots and shoots, air and oven dried and weighed to obtain fresh and dry matter yield of shoots and roots. The dried plant materials were analyzed for its content of N, P, K and B. The obtained results showed that the best growth (high dry matter yield) of barley shoots was obtained at $60 \mathrm{mg} \mathrm{L}^{-1} \mathrm{~N}$ and $2 \mathrm{mg} \mathrm{L}^{-1} \mathrm{~B}$. For roots, increasing B concentrations in the culture showed negative effect on root dry matter yield. Application of B increased markedly B uptake by shoots and roots. Also, application of $\mathrm{N}$ increased B uptake by shoots and roots and seemed to reduce the injurious effect of B. Moreover, uptake of nitrogen by shoots and roots increased progressively with increasing $\mathrm{N}$ levels and $\mathrm{B}$ concentration up to $2 \mathrm{mg} \mathrm{L}^{-1}$. The results also indicated that, uptake of $\mathrm{P}$ and $\mathrm{K}$ tended to increase with increasing $\mathrm{B}$ concentration in the range of 2 to $3 \mathrm{mg} \mathrm{L}^{-1}$. Further increase in $\mathrm{B}$ rates decreased the uptake of $\mathrm{P}$ and $\mathrm{K}$ by plant.

Keywords: Nitrogen-Boron, Water culture technique, Barley and Nutrients Uptake.

\section{INTRODUCTION}

Boron is an essential micronutrient for plant, but the range between deficient and toxic boron concentrations is smaller than any other nutrient. Plants directly respond to the active boron in soil solution and indirectly to adsorbed boron on soil constituent (Goldberg, 1997). Cereals, in general are sensitive to B levels, consequently care must be taken into consideration when cereals are planted after the crops require high rates of B. Abdel-Mottaleb et al. (1986) found that the dry matter yield of barely shoot significantly increased with increasing B Concentration to certain level and then it decreased by further increase in B. Inal and Tarakcioglu (2008) indicated that Increasing B in nutrient solution increased the $\mathrm{B}$ contents of plants.

On the other hand another works indicated that the cereals grown on soil-compost high in B were subjected to B toxicity (Gupta et al., 1973) and (Marschner, 1998).

Many works found that liberal application of $\mathrm{N}$ are sometimes beneficial in controlling excess B in citrus (Chapman and Vanselow, 1955) and in wheat (Pecznik et al., 1971 and Chauhan et al., 1972). They found also that $\mathrm{N}$ application at any rate in combination with $\mathrm{B}$ caused a significant increase in yield of wheat comparison with control. Jiang et al. (1994) revealed that maximum NPK uptake was obtained when $B$ was added at $1 \mathrm{mg} \mathrm{L}^{-1}$, but the further increasing in B level caused a great reduction in NPK uptake. Similar results were obtained by Fathi (1983) who stated that a harmful effect of high boron levels on dry matter yield and $\mathrm{K}$ concentration in both shoot and roots of plants.

This work aims to investigate the interactions between boron and nitrogen on dry matter yield of barely plants and its uptake of N, P, K and B. Also, effect of different $\mathrm{B}$ application on plant requirement of $\mathrm{N}$ was studied.

\section{MATERIALS AND METHODS}

This experiment was carried out at soil science department, Faculty of Agriculture, Menoufia University to study the effect of either nitrogen $(\mathrm{N})$ or boron $(\mathrm{B})$ on barely plants under water culture technique condition.
This experiment was conducted using water culture technique in 1.0 liter plastic pots having $8.0 \mathrm{~cm}$ diameter and $18.0 \mathrm{~cm}$ depth, covered with painted plastic cover containing 8 holes for planting seedlings and two holes for air tubing and the addition of water or nutrient solution . All pots were aerated continuously, where the aeration outlet units were submerged in the nutrient solution, Barley Hordeum vulgare L (variety Giza 123) was chosen as attest plant. The experiment was designed as split plots in factorial arrangement with three replicates. Barely seeds were soaked for 24 hours in aerated distilled water using a water suction pump and germinated over cotton fiber saturated with water for one day. After 7 days eight seeding were transferred on the holes of the plastic cover of pots containing distilled water. Then Hoagland nutrient solution without addition of the tested nutrients was added every five days. Table (1) shows the chemical composition of the used nutrient solution

Table (1) Chemical composition of the used nutrient solution (Hoagland nutrient solution)

\begin{tabular}{lcc}
\hline $\begin{array}{l}\text { Nutrient } \\
\text { Source }\end{array}$ & $\begin{array}{c}\text { Concentration of } \\
\text { stock solution }\end{array}$ & $\begin{array}{c}\text { Per liter of nutrient } \\
\text { solution }\end{array}$ \\
\hline $\mathrm{Ca}\left(\mathrm{H}_{2} \mathrm{PO}_{4}\right)_{2} \cdot \mathrm{H}_{2} \mathrm{O}$ & $0.05 \mathrm{M}$ & $10 \mathrm{ml}$ \\
$\mathrm{CaSO}_{4} \cdot 2 \mathrm{H}_{2} \mathrm{O}$ & $0.01 \mathrm{M}$ & $200 \mathrm{ml}$ \\
$\mathrm{K}_{2} \mathrm{SO}_{4}$ & $0.5 \mathrm{M}$ & $5 \mathrm{ml}$ \\
$\mathrm{MgSO}_{4} \cdot 7 \mathrm{H}_{2} \mathrm{O}$ & $1 \mathrm{M}$ & $2 \mathrm{ml}$ \\
$\mathrm{MnCl}_{2} \cdot 4 \mathrm{H}_{2} \mathrm{O}$ & $1.81 \mathrm{~g} \mathrm{~L}^{-1}$ & $1 \mathrm{ml}$ \\
$\mathrm{ZnSO}_{4} \cdot 7 \mathrm{H}_{2} \mathrm{O}$ & $0.22 \mathrm{~g} \mathrm{~L}^{-1}$ & $1 \mathrm{ml}$ \\
$\mathrm{CuSO}_{4} \cdot 5 \mathrm{H}_{2} \mathrm{O}$ & $0.08 \mathrm{~g} \mathrm{~L}^{-1}$ & $1 \mathrm{ml}$ \\
$\mathrm{H}_{2} \mathrm{MoO} 4 . \mathrm{H}_{2} \mathrm{O}$ & $0.02 \mathrm{~g} \mathrm{~L}^{-1}$ & $1 \mathrm{ml}$ \\
Fe-EDTA & $1.00 \mathrm{~g} \mathrm{~L}^{-1}$ & $1 \mathrm{ml}$ \\
\hline
\end{tabular}

Nitrogen was applied at the levels of $0,30,60$ and $90 \mathrm{mg} \mathrm{N} \mathrm{L}^{-1}$ as $\mathrm{NH}_{4} \mathrm{NO}_{3}$. However, boron was added at the levels of $0,2,3,6$, and $9 \mathrm{mg} \mathrm{B} \mathrm{L}^{-1}$ as $\mathrm{H}_{3} \mathrm{BO}_{3}(17.48 \%$ B). Treatments were added every two days within the period extending from 9 to 40 days after cultivation. After 42 days of seedling, the plants of each pot were harvested, leached several times with tap water followed by two times by distilled water, divided into roots and shoots, weighed to determine fresh weight, air dried and oven dried at $70^{\circ} \mathrm{c}$ for 48 hours, weighed to determine dry weight, ground and kept for chemical analyses. The obtained data of both fresh and dry weight 
of barely plants (roots and shoots) were statistically analyzed according to Snedecor and Cochran (1994).

A $0.2 \mathrm{~g}$ of each dried plant material was digested by $5 \mathrm{ml}$ of mixed concentrated $\mathrm{H}_{2} \mathrm{SO}_{4}$ and $\mathrm{HClO}_{4}$ acids at ratio of $3: 1$ according to the method described by Chapman and Pratt (1961). The contents of N, P, K, and $\mathrm{B}$ were determined in the digest solution according to the methods described by Cottenie et al. (1982).

\section{RESULTS AND DISCUSSION}

\section{Fresh and dry matter yield of barely plants}

Fresh and dry matter yield $\left(\mathrm{g} \mathrm{pot}^{-1}\right)$ of shoots slightly increased with increasing boron concentration up to $2 \mathrm{mg} \mathrm{L}^{-1}$ as shown in Table (2). On the other hand, significant depression in the dry matter yield of shoots is observed with increasing boron level more than $2 \mathrm{mg}$ $\mathrm{L}^{-1}$. As regards of roots, the fresh and dry matter yield generally decreased with increasing levels of boron over $3 \mathrm{mg} \mathrm{L}{ }^{-1}$. This decrease in both fresh and dry matter yield of shoots and roots is presumably due to excessive boron accumulation in the plant tissue causing specific action on the nitrogen metabolic chin. These results are in agreements with those obtained by Bonilla et al.,(1980); Fathi (1983); Abdel-Mottaleb et al.(1986) and Proctor and Shelp (2013).

Data in Table (2) also revealed that increasing levels of added nitrogen from 0 to $60 \mathrm{mg} \mathrm{L}^{-1}$ increased the fresh and dry matter yield of both shoots and roots. However, nitrogen application higher than this level resulted in a slight decrease in the fresh and dry matter yield of shoots. This was attributed to the adverse effect of increasing nitrogen on the uptake of and translocation of other nutrients (Fathi, 1983).

In addition, the interaction treatments of boron and nitrogen were associated by an increase and significant effect on the fresh and dry matter yield of shoots and roots (Table 2). The best result for shoots was obtained on the addition $2 \mathrm{mg} \mathrm{B} \mathrm{L}^{-1}$ and $60 \mathrm{mg} \mathrm{N} \mathrm{L}^{-}$ ${ }^{1}$, where the best result for roots was found with $2 \mathrm{mg} \mathrm{B}$ $\mathrm{L}^{-1}$ and $90 \mathrm{mg} \mathrm{N} \mathrm{L}^{-1}$.

Table (2): Fresh and dry matter yield $\left(\mathrm{g} \mathrm{pot}^{-1}\right)$ of barely plants (shoots and roots) affected by different application of $\mathrm{N}$ and $\mathrm{B}$.

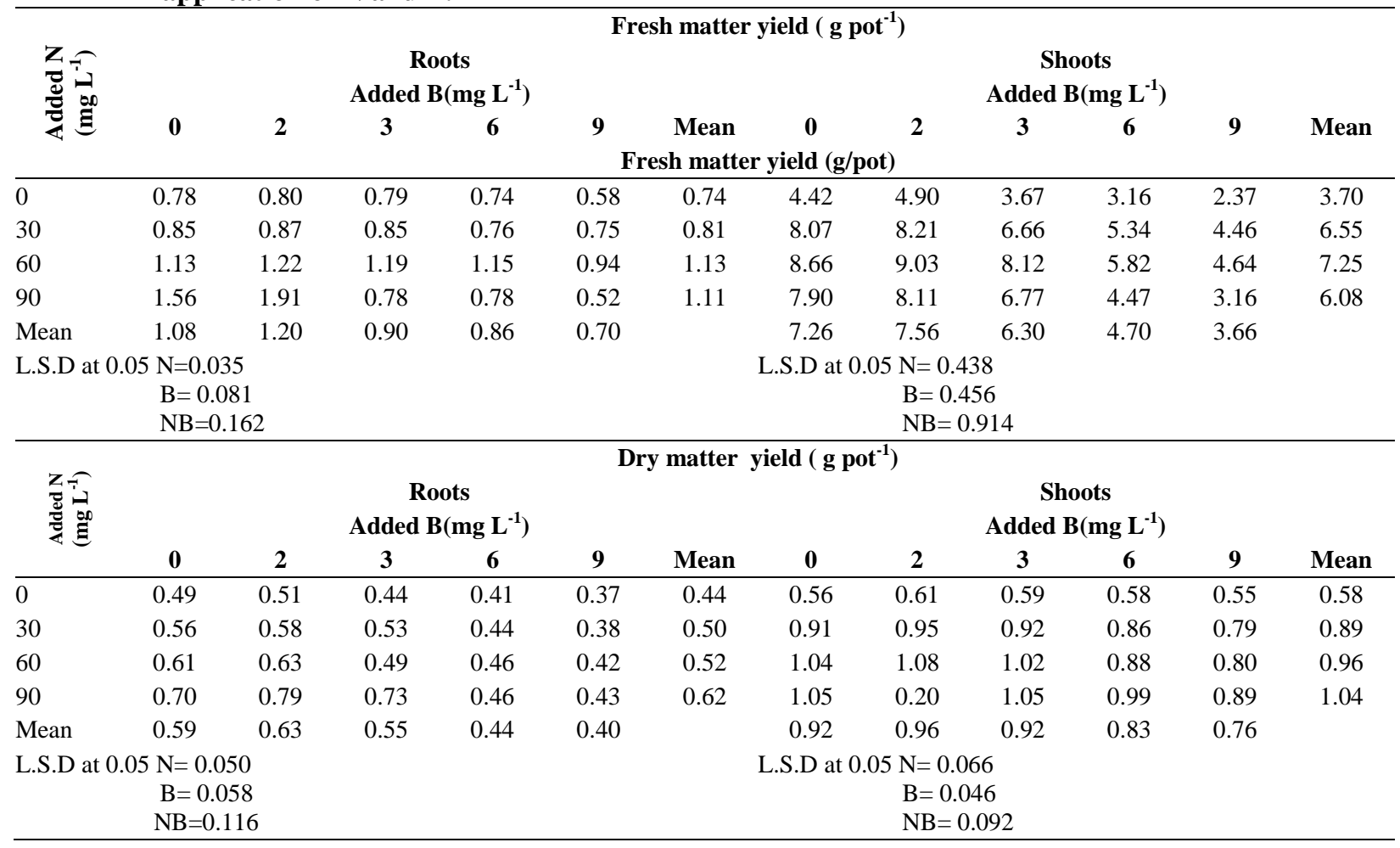

\section{Nitrogen content}

The effect of applied $\mathrm{N}$ and $\mathrm{B}$ individually or together on $\mathrm{N}$ concentration $\left(\mathrm{mg} \mathrm{g}^{-1}\right)$ and uptake (mg pot ${ }^{-1}$ ) by barely plants is shown in Table (3). Increasing nitrogen rates from 0 to $90 \mathrm{mg} \mathrm{L}^{-1}$ in the culture media progressively increased nitrogen concentration and uptake by both shoots and roots at all added levels of boron. Data indicated that applied boron at rates of 3,6 and $9 \mathrm{mg} \mathrm{L}^{-1}$ markedly increased nitrogen uptake by shoots and contrary with roots. This decrease in nitrogen uptake by roots is mainly due to pronounced harmful effect of added boron on the dry matter yield. In this connection, Fathi (1983) found that increasing of added B in the cultural media from 2.5 to $10 \mathrm{mg} \mathrm{L}^{-1}$ markedly decreased the uptake of nitrogen. Data also clarified that, there was significant interaction effect of $\mathrm{B}$ and $\mathrm{N}$ on $\mathrm{N}$ uptake by shoots and roots (Table 3). 
Table (3) Nitrogen concentration $\left(\mathrm{mg} \mathrm{g}^{-1}\right)$ and uptake $\left(\mathrm{mg} \mathrm{pot}^{-1}\right)$ by barely plants (roots and shoots) as affected by different application of $\mathrm{N}$ and $\mathrm{B}$.

\begin{tabular}{|c|c|c|c|c|c|c|c|c|c|c|c|c|c|c|c|c|c|c|c|c|c|c|c|c|}
\hline \multirow[b]{3}{*}{ 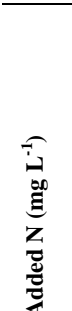 } & \multicolumn{12}{|c|}{$\begin{array}{c}\text { Roots } \\
\text { Added B }\left(\mathrm{mg} \mathrm{L}^{-1}\right)\end{array}$} & \multicolumn{12}{|c|}{$\begin{array}{c}\text { Shoots } \\
\text { Added B }\left(\mathrm{mg} \mathrm{L}^{-1}\right)\end{array}$} \\
\hline & \multicolumn{2}{|c|}{ 0 } & \multicolumn{2}{|c|}{2} & \multicolumn{2}{|c|}{3} & \multicolumn{2}{|c|}{6} & \multicolumn{2}{|c|}{9} & \multicolumn{2}{|c|}{ Mean } & \multicolumn{2}{|c|}{0} & \multicolumn{2}{|c|}{2} & \multicolumn{2}{|c|}{3} & \multicolumn{2}{|c|}{6} & \multicolumn{2}{|c|}{9} & \multicolumn{2}{|c|}{ Mean } \\
\hline & 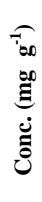 & 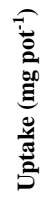 & 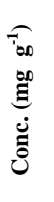 & 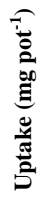 & 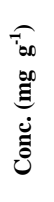 & 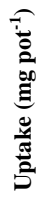 & 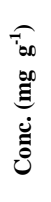 & 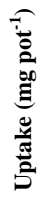 & 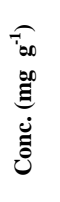 & 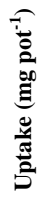 & 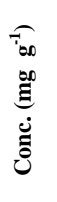 & 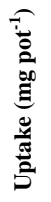 & 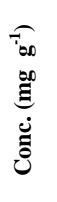 & 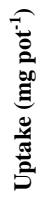 & 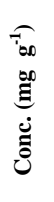 & 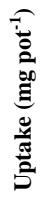 & 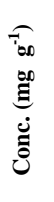 & 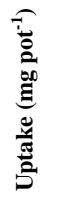 & 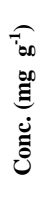 & 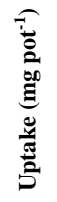 & 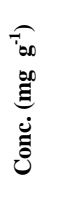 & 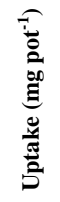 & 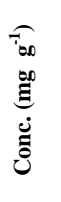 & 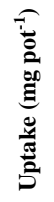 \\
\hline
\end{tabular}

\begin{tabular}{lllllllllllllllllllllllllll}
\hline 0 & 12.21 & 5.98 & 11.20 & 5.67 & 10.18 & 4.47 & 6.11 & 2.51 & 6.11 & 2.28 & 9.16 & 4.18 & 11.18 & 6.26 & 11.00 & 6.75 & 12.21 & 7.20 & 24.42 & 14.24 & 16.28 & 8.96 & 16.86 & 8.86
\end{tabular} $\begin{array}{lllllllllllllllllllllllll}30 & 12.21 & 7.45 & 16.28 & 10.20 & 20.35 & 10.04 & 20.35 & 9.29 & 16.28 & 6.84 & 17.09 & 8.76 & 36.63 & 33.33 & 35.63 & 33.73 & 34.60 & 31.72 & 28.49 & 24.60 & 20.35 & 16.14 & 31.14 & 27.90\end{array}$ $\begin{array}{lllllllllllllllllllllllllllll}60 & 24.42 & 13.68 & 20.35 & 11.06 & 16.28 & 8.58 & 15.26 & 6.67 & 14.25 & 5.42 & 18.11 & 9.08 & 39.48 & 41.03 & 38.06 & 41.11 & 36.63 & 37.24 & 34.77 & 30.36 & 28.49 & 22.79 & 35.49 & 34.51\end{array}$ $\begin{array}{lllllllllllllllllllllllllllll}90 & 30.53 & 21.37 & 29.51 & 23.31 & 28.49 & 20.70 & 28.49 & 13.20 & 26.46 & 11.29 & 28.71 & 17.97 & 48.84 & 46.40 & 46.90 & 47.06 & 44.95 & 42.70 & 38.67 & 30.42 & 34.60 & 23.76 & 42.79 & 38.07\end{array}$

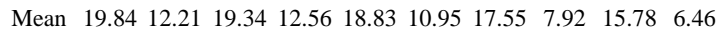

\section{Phosphorus and potassium content}

Regarding the data of $\mathrm{P}$ and $\mathrm{K}$ concentration $\left(\mathrm{mg} \mathrm{g}^{-1}\right)$ and uptake (mg pot $\left.^{-1}\right)$ by barely plants as affected by $\mathrm{B}$ concentration in the water culture, the data in table 4 and 5 revealed that the uptake of both $\mathrm{P}$ and $\mathrm{K}$ by barely plants, in relation with the studied treatments of $\mathrm{N}$ and $\mathrm{B}$, followed the same trend of $\mathrm{N}$ content and uptake. The highest increase of $\mathrm{P}$ uptake resulted from the addition of 3 and $2 \mathrm{mg} \mathrm{B} \mathrm{L}^{-1}$ for shoots and roots respectively. Also the highest value of $\mathrm{K}$ uptake was observed at the addition of $2 \mathrm{mg} \mathrm{B} \mathrm{L}^{-1}$ for shoots and roots. Further increase in $\mathrm{B}$ concentration resulted in remarkable reduction in $\mathrm{P}$ and $\mathrm{K}$ uptake. This reduction in $\mathrm{P}$ and $\mathrm{K}$ uptake was indirectly due to remarkable decrease in dry matter yield caused by high $\begin{array}{llllllllll}34.02 & 31.76 & 25.20 & 32.16 & 32.10 & 29.72 & 31.59 & 24.91 & 24.93 & 17.91\end{array}$

rates of $\mathrm{B}$ addition. These results are in agreement with those obtained by Fathi (1983) who reported harmful effect of higher levels of B on dry matter yield and K concentration. Cauhan and Powar (1978) found that applying $\mathrm{B}$ at levels of 2.5 and $5 \mathrm{mg} \mathrm{L}^{-1}$ markedly increased $\mathrm{N}$ concentration. However, further increase in $\mathrm{B}$ level in the growth medium was followed by a significant decrease in $\mathrm{N}$ concentration. This decease may be due to B toxicity. Gupta et al. (1976) and ElSayed (1990) indicated that $\mathrm{P}$ concentration was not significantly affected by increasing $B$ concentration up to $5 \mathrm{mg} \mathrm{L}^{-1}$. conversely, added $\mathrm{B}$ at rates of 6 and $9 \mathrm{mg}$ $\mathrm{L}^{-1}$ resulted in markedly decline in $\mathrm{P}$ concentration. This could be due to observed lower plant growth rate at higher B levels.

Table (4) phosphorus concentration $\left(\mathrm{mg} \mathrm{g}^{-1}\right)$ and uptake $\left(\mathrm{mg} \mathrm{pot}^{-1}\right)$ by barely plants (roots and shoots) as affected by different application of $\mathrm{N}$ and $\mathrm{B}$.

\begin{tabular}{|c|c|c|c|c|c|c|c|c|c|c|c|c|c|c|c|c|c|c|c|c|c|c|c|c|}
\hline \multirow[b]{3}{*}{ 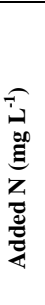 } & \multicolumn{12}{|c|}{$\begin{array}{c}\text { Roots } \\
\text { Added } B\left(\mathrm{mg} \mathrm{L}^{-1}\right)\end{array}$} & \multicolumn{12}{|c|}{$\begin{array}{c}\text { Shoots } \\
\text { Added B }\left(\mathrm{mg} \mathrm{L}^{-1}\right)\end{array}$} \\
\hline & & 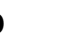 & 2 & 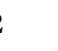 & 3 & & & & & & & & & ) & 2 & 2 & 3 & & $p$ & 6 & & 9 & $\mathbf{M e}$ & an \\
\hline & 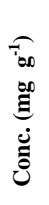 & 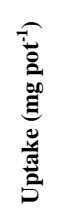 & 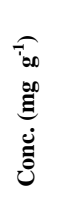 & 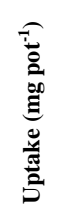 & 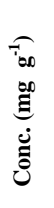 & 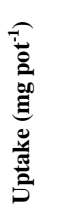 & 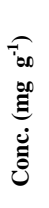 & 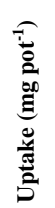 & 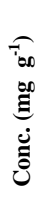 & 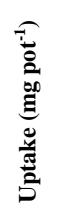 & 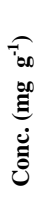 & 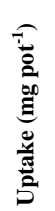 & 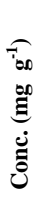 & 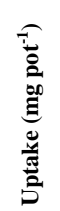 & 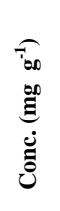 & 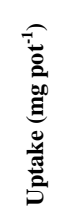 & 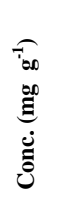 & 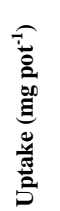 & 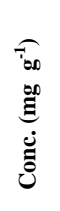 & 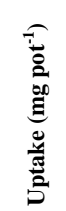 & 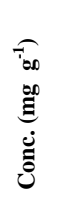 & 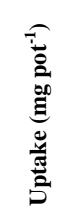 & 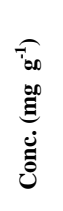 & 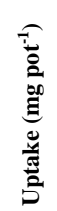 \\
\hline
\end{tabular}

\begin{tabular}{llllllllllllllllllllllllllllll}
\hline 0 & 3.53 & 1.73 & 3.58 & 1.81 & 3.62 & 1.59 & 3.70 & 1.52 & 3.53 & 1.32 & 3.60 & 1.59 & 4.85 & 2.79 & 5.26 & 3.23 & 5.52 & 3.26 & 5.52 & 3.22 & 5.00 & 2.75 & 5.23 & 3.05
\end{tabular}

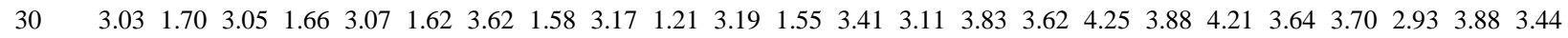

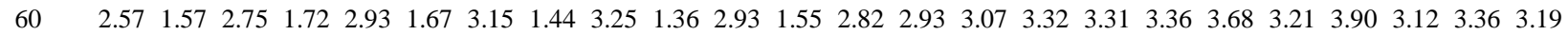
$\begin{array}{llllllllllllllllllllllllll}90 & 2.47 & 1.73 & 2.70 & 2.14 & 2.93 & 2.13 & 3.41 & 1.58 & 2.47 & 1.05 & 2.80 & 1.73 & 2.58 & 2.44 & 2.88 & 2.89 & 3.00 & 2.85 & 3.09 & 2.43 & 3.00 & 2.06 & 2.91 & 2.53\end{array}$ $\begin{array}{lllllllllllllllllllllll}\text { Mean } & 2.90 & 1.68 & 3.02 & 1.83 & 3.14 & 1.75 & 3.47 & 1.53 & 3.11 & 1.24 & 3.13 & & 3.42 & 2.82 & 3.76 & 3.27 & 4.02 & 3.34 & 4.13 & 3.13 & 3.90 & 2.72\end{array}$

Table (5) Potassium concentration $\left(\mathrm{mg} \mathrm{g}^{-1}\right)$ and uptake ( $\mathrm{mg} \mathrm{pot}^{-1}$ ) by barely plants (roots and shoots) as affected by different application of $\mathrm{N}$ and $\mathrm{B}$.

\begin{tabular}{|c|c|c|c|c|c|c|c|c|c|c|c|c|c|c|c|c|c|c|c|c|c|c|c|c|}
\hline \multirow[b]{3}{*}{ 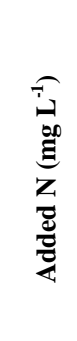 } & \multicolumn{12}{|c|}{$\begin{array}{c}\text { Roots } \\
\left.\text { Added B(mg L }{ }^{-1}\right)\end{array}$} & \multicolumn{12}{|c|}{$\begin{array}{c}\text { Shoots } \\
\left.\text { Added B(mg L }{ }^{-1}\right)\end{array}$} \\
\hline & & 0 & 2 & & & 3 & & 6 & 9 & 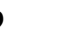 & Me & ean & $\mathbf{0}$ & 0 & 2 & 2 & 3 & & 6 & 6 & & 9 & Me & ean \\
\hline & 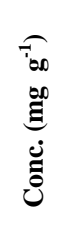 & 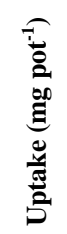 & 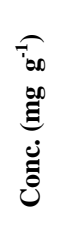 & 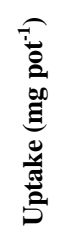 & 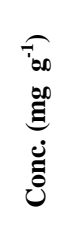 & 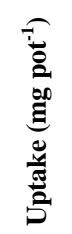 & 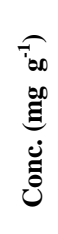 & 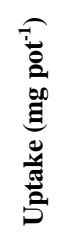 & 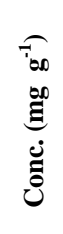 & 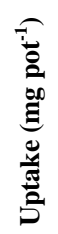 & 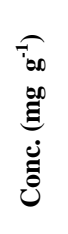 & 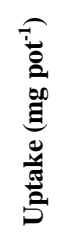 & $\begin{array}{l}\text { To } \\
00 \\
\dot{\Xi} \\
\dot{\Xi} \\
\ddot{\Xi}\end{array}$ & 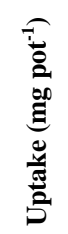 & 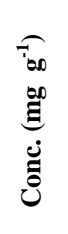 & 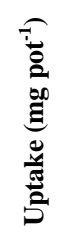 & 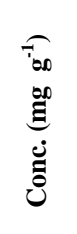 & 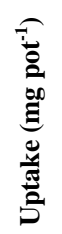 & 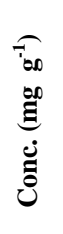 & 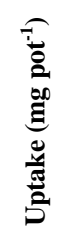 & 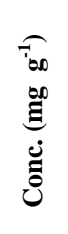 & 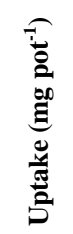 & 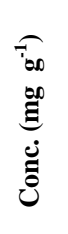 & 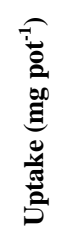 \\
\hline 0 & 17.2 & 8.4 & 17.5 & 8.9 & 17.8 & 7.8 & 18.5 & 7.6 & $1 / .8$ & 6.6 & 17.8 & 1.9 & 1 & 20.2 & 36.3 & .2 & 36.5 & 21.5 & 36.5 & 21.3 & 35.4 & 19.5 & 36.2 & 20.9 \\
\hline 30 & 21.5 & 12.0 & 21.7 & 11.8 & 21.9 & 11.7 & 22.4 & 9.8 & 22.8 & 8.7 & 22.1 & 10.8 & 44.1 & 40.1 & 44.2 & 41.8 & 44.3 & 40.6 & 44.6 & 38.5 & 44.9 & 35.6 & 44.4 & 39.3 \\
\hline 60 & 20.1 & 12.3 & 20.2 & 12.7 & 21.5 & 10.6 & 20.5 & 9.3 & 19.5 & 8.2 & 20.4 & 10.6 & 47.0 & 48.9 & 46.0 & 49.7 & 45.0 & 45.8 & 43.1 & 37.6 & 40.8 & 32.6 & 44.4 & 42.9 \\
\hline 90 & 16.2 & 11.3 & 16.8 & 13.3 & 17.4 & 12.7 & 18.0 & 10.6 & 20.3 & 8.6 & 17.8 & 11.3 & 40.0 & 38.0 & 43.2 & 43.3 & 46.3 & 44.0 & 46.5 & 36.6 & 46.7 & 32.1 & 44.5 & 38.8 \\
\hline Mean & 18.8 & 11.0 & 19.1 & 11.7 & 19.7 & 10.7 & 19.8 & 9.3 & 20.1 & 8.0 & & & 41.8 & 36.8 & 42.4 & 39.3 & 43.0 & 38.0 & 42.7 & 33.5 & 42.0 & 30.0 & & \\
\hline
\end{tabular}


Increasing $\mathrm{N}$ rate from 30 to $60 \mathrm{mg} \mathrm{L}^{-1}$ in the cultural media increased $\mathrm{P}$ uptake by shoots, where $\mathrm{K}$ uptake increased with increasing added $\mathrm{N}$ to $90 \mathrm{mg} \mathrm{L}^{-1}$. For roots, at all levels of $\mathrm{N}$ and $\mathrm{B}, \mathrm{K}$ concentration and uptake were increased (Table 5). In this respect, Mohidin et al.(2015) obtained similar results.

Data in table (4) also clarified that there was no significant effect of the interaction between $\mathrm{N}$ and $\mathrm{B}$ on $\mathrm{P}$ uptake by shoots and roots. In contrary, $\mathrm{K}$ uptake was significantly affected by the combination of $\mathrm{N}$ and $\mathrm{B}$ (Table 5). The results are in agreements with those obtained by Tariq and Mott (2006).

\section{Boron content}

Data in Table (6) indicate that the addition of 9 $\mathrm{mg} \mathrm{B} \mathrm{L}{ }^{-1}$ increased $\mathrm{B}$ concentration $\left(\mathrm{mg} \mathrm{kg}^{-1}\right)$ and uptake $\left(\mathrm{mg} \mathrm{pot}^{-1}\right)$ by shoots and decreased its uptake by roots. This hold true for nitrogen treatment. The results are in agreements with other reports (Touchton and Bosewell, 1975 and Aduayi, 1978). It is also apparent that increasing the rate of applied $\mathrm{N}$ from 60 to $90 \mathrm{mg} \mathrm{L}^{-}$

${ }^{1}$ increased B uptake by shoots and roots, however B uptake by roots was not significantly affected. This effect of nitrogen on B uptake is mainly due to the marked increase in dry matter yield at this level of nitrogen. However, applied nitrogen at level of $90 \mathrm{mg} \mathrm{L}^{-}$ ${ }^{1}$ markedly decreased B uptake by at all levels of B. Also the results clearly showed that most boron taken up by barely plants was translocated to the shoots and consequently less boron was retained in roots. Data also revealed that, there is a significant increase of $B$ uptake by shoots of barely plants as a result of $\mathrm{N}$ and $\mathrm{B}$ application. However, the same treatments had no significant effect on B uptake by roots. In this respect Bogiani et al. (2014) obtained similar results

Table (6) Boron concentration $\left(\mathrm{mg} \mathrm{kg}^{-1}\right)$ and uptake $\left(\mathrm{mg} \mathrm{pot}^{-1}\right)$ by barely plants (roots and shoots) as affected by different application of $\mathrm{N}$ and $\mathrm{B}$

\begin{tabular}{|c|c|c|c|c|c|c|c|c|c|c|c|c|c|c|c|c|c|c|c|c|c|c|c|c|}
\hline \multirow[b]{3}{*}{ 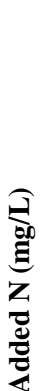 } & \multicolumn{12}{|c|}{$\begin{array}{c}\text { Roots } \\
\text { Added B }\left(\mathrm{mg} \mathrm{L}^{-1}\right)\end{array}$} & \multicolumn{12}{|c|}{$\begin{array}{c}\text { Shoots } \\
\text { Added B }\left(\mathrm{mg} \mathrm{L}^{-1}\right)\end{array}$} \\
\hline & \multicolumn{2}{|c|}{$\mathbf{0}$} & \multicolumn{2}{|c|}{2} & \multicolumn{2}{|c|}{3} & \multicolumn{2}{|c|}{6} & \multicolumn{2}{|c|}{9} & \multicolumn{2}{|c|}{ Mean } & \multicolumn{2}{|c|}{ 0 } & \multicolumn{2}{|c|}{2} & \multicolumn{2}{|c|}{3} & \multicolumn{2}{|c|}{6} & \multicolumn{2}{|c|}{9} & \multicolumn{2}{|c|}{ Mean } \\
\hline & 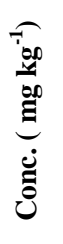 & 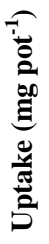 & 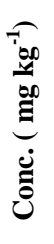 & 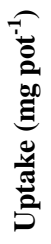 & 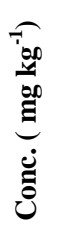 & 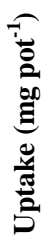 & 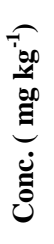 & 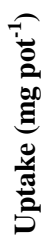 & 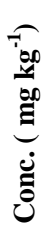 & 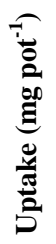 & 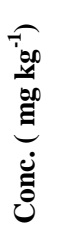 & 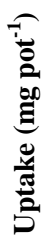 & 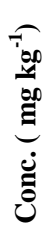 & 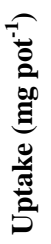 & 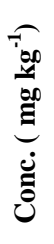 & 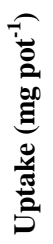 & 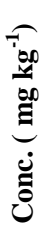 & 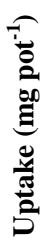 & 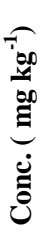 & 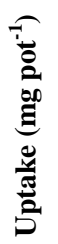 & 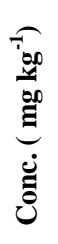 & 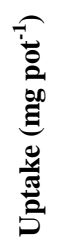 & 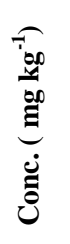 & 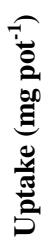 \\
\hline
\end{tabular}

\begin{tabular}{lllllllllllllllllllllllllll}
\hline 0 & 11.0 & 6.16 & 13.0 & 6.80 & 14.0 & 7.14 & 16.0 & 7.31 & 18.0 & 7.80 & 14.4 & 7.04 & 8.0 & 4.48 & 9.0 & 5.53 & 11.0 & 6.49 & 14.0 & 8.17 & 15.0 & 8.25 & 11.4 & 60.58
\end{tabular}

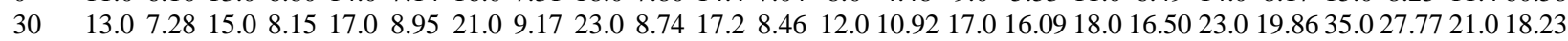

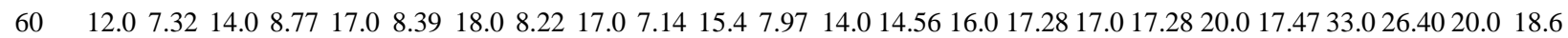

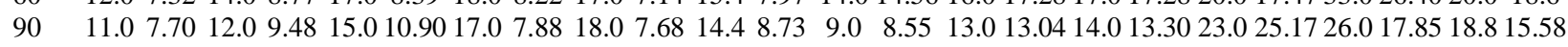
Mean11.75 7.12 $13.5 \quad 8.30 \quad 15.5 \quad 8.85 \quad 17.0 \quad 8.15 \quad 19.0 \quad 7.84$ 10.759 .6313 .7512 .9914 .513 .3922 .2517 .6727 .2520 .07

\section{CONCLUSION}

From the aforementioned results, it is quite clear that, nitrogen application plays major role in controlling the boron toxicity problem, on the contrary, nitrogen in the media containing low concentration of boron could aggravate a boron symptoms deficiency on plants. It has been clarified that plants will grow normally when a certain balance in the intake of boron and nitrogen exists .This balance between both nutrients might eliminate the unfavorable effect of boron on nitrogen metabolism in plant tissues.

\section{REFERENCES}

Aduayi, E. A. (1978): Role of boron on growth components and elemental composition of tomato. Communication in soil, Science and Plant Analysis, 9:1-11.

Abdel-Mottaleb, S. M., Abdel Aziz, S. and Dimian, W.N. (1986): Boron-Nitrogen interrelation in barely plants. Annals of Agric. Sic.Moshtohor:24(4).

Bogiani, J. C., Sampaio T. F., Abreu-Junior C. H. and Rosolem C. A. (2014) Boron uptake and translocation in some cotton cultivars. Plant and Soil 375(1) :241-253.
Bonlilla, I. C., Cadahia, C.O. and Hernandio, V. (1980): Effect of boron on metabolism and sugar levels of sugar beet. Plant and soil, 57:3 -9.

Chapman, H.D., and Pratt, P.F (1961). Methods of analysis for soils, plants and waters. Division of Agricultural Sciences, University of California, Riverside.

Chapman, H. D. and Vanselow, A.P.(1955): Boron deficiency and excess Calif. Citrogr 40:31-34.

Chauhan , R. P.S. and Power ,S.L.(1978):Tolerance of wheat and pea to boron in irrigation water. Plant and Soi1.50:145-149.

Chauhan, R. S., Singh, H. K., Singh, R. R. and Dandwate, M.D.(1972): Effect of foliar application of micronutrients on wheat .Journal of Agricultural and Scientific Research. 14(2): 100-102.

Cottenie, Verloo, A. M., Kiekens L., Velgh G. and Camerlynck R. (1982): Chemical Analysis of Plants and Soils.. State Univ. Ghent Belgium.

El-Sayed, A. H.(1990): Effect of drainage water quality on soil and plant. M.Sc. Thesis, Fac.Agric.,Ain Shams Univ., Egypt.

Fathi, A. I. (1983): Studies on the uptake and tolerance of some trace elements by plants. Ph. D. Thesis Fac. of Agric., Ain Shams Univ. 
Gupta, I. C., Macleod, J. A. and Sterling, I. D. E. (1976): Effect of boron and nitrogen on grain yield and boron and nitrogen concentration of barley and wheat. Soil Sci. J. 40:723-726.

Goldberg, S. (1997): Reaction of boron with soils. Plant and soil;193(1-2)35-48.

Gupta, U. C., Sterling, J. D. E. and Nass, H.G.(1973): Influence of various rates of compost and nitrogen on the boron toxicity symptoms in barley and wheat. Can. J. plant Sci.53:451-456.

Inal A. and Tarakcioglu C. (2008): Effects of nitrogen forms on growth, nitrate accumulation, membrane permeability, and nitrogen use efficiency of hydroponically grown bunch onion under boron deficiency and toxicity. Journal of Plant Nutrition. 24(10)1521-1534.

Jiang, R. F., Zhang, Q. G. and Zhang, F.S. (1994): The effects of application of boron on nitrogen uptake and nitrogen fixation in groundnuts. Acta-Agriculture universitatis - Pekinensis.

Marschner, H. (1998): Mineral Nutrition of Higher Plants, London: Academic Press.
Mohidin, H. , Hanafi M. M., Rafii Y. M., Abdullah, S. N. A., Idris A., Man S., Idris J. and Sahebi M. (2015) : Determination of optimum levels of nitrogen, phosphorus and potassium of oil palm seedlings in solution culture. Bragantia, Campinas, 74(3): 247-254.

Pecznic, J., Kovacs, K. and Kiss, T. (1971): The effect of various trace element on the quality and quantity of wheat yield. Buzatermesztesi kiserletek 1960-1970: 407-419.

Proctor, J. T.A. and Shelp B J. (2013): Effect of boron nutrition on American ginseng in field and in nutrient cultures. Jornal of Ginseng Research, 38: 73-77.

Snedecor, G. W. and Cochran W. G. (1994): Statistical Methods. $8^{\text {th }}$ Edn IOWA State University Press, Ames, IOWA, USA.

Tariq, M. and Mott, C.J.B. (2006) Effect of applied boron on the accumulation of cations and their ratios to boron in radish (Raphanus sativus L.) Soil and Environ. 25(1): 40-47.

Touchton, J. T. and Bosewell F.C. (1975): Boron application for corn grown on selected southeastern soils. Agron. J. 67:197-200.

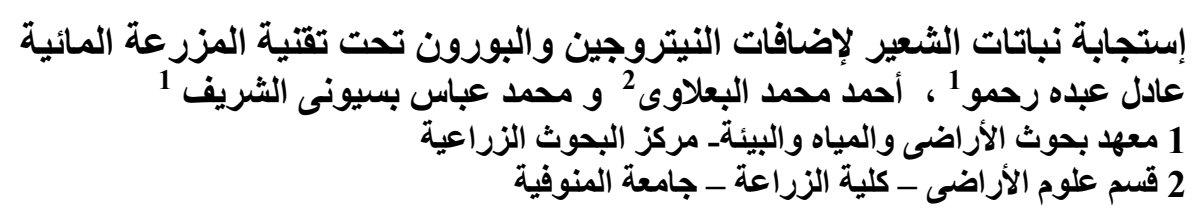

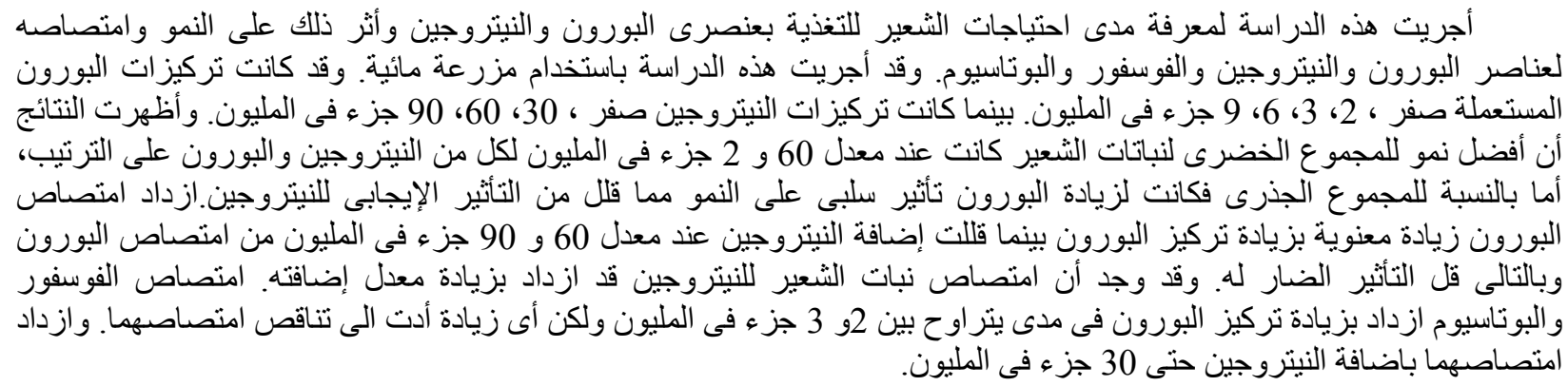

